\title{
Decomposition English and Mandailing Prefixes: A Contrastive Study
}

\author{
Muhammad Hasyimsyah Batubara', Vidya Dwi Amalia Zati² \& Sani Susanti ${ }^{3}$ \\ ${ }^{1}$ Faculty of Education, State Institute of Islamic Studies Takengon, Indonesia \& ${ }^{2 \& 3}$ Faculty of Education, Universitas \\ Negeri Medan, Indonesia
}

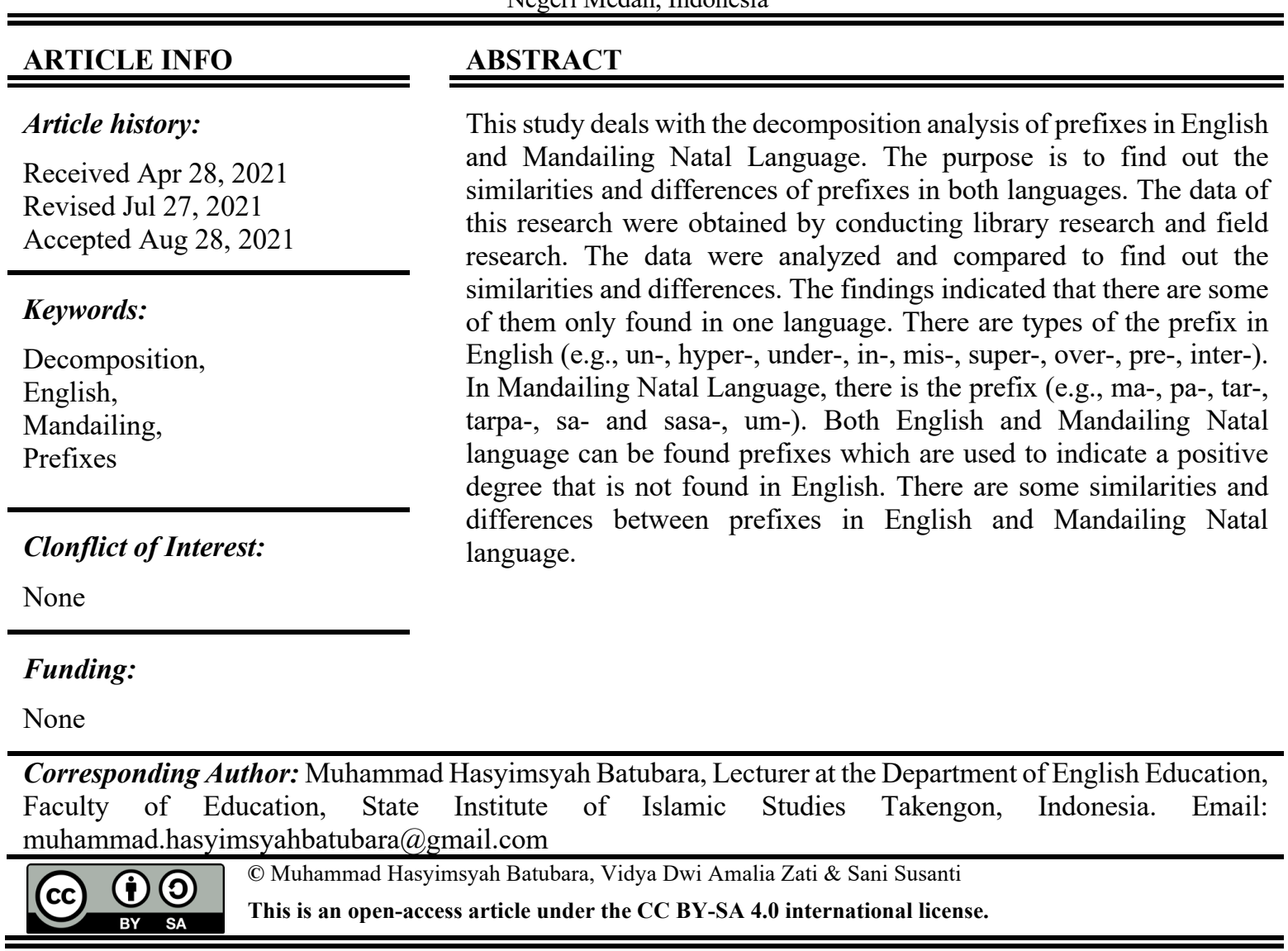

1. Introduction

Language is the core mean of communication, and all human beings use language to interact with other members of the same community. According to Finch (1998), language has defined two functions, as a micro function: for the realist nerve or physical energy/psychological function, for phatic function/socialization purposes, recording function/to provide notes, identification function/to identify and classify things, the function of reasoning/as an instrument of thought, communication function/as a means of communication of ideas and function of pleasure/feelings, giving joy, and next as a macro function: ideational functions, interpersonal functions, poetic function, textual function. There are two kinds of language, namely written and spoken language. Besides, there is also a body language used to convey meaning through a gesture, eye contact, and facial expression. Besides, the expression as a vehicle for the exchange of thoughts, concepts, knowledge, and information as well as the regulation and transmission of experiences and knowledge, this understanding sees and are based on language only as a cognitive process, subject to social factors and subject to change, and historical development (Batubara, 2020). Indeed, Gellner (1983); Walter (1988); Anderson (1991); Wright (2004; 2015) stated language as a system and nation-building.

Indonesia, as a developing country, uses Indonesian as the official language. Besides that, the foreign language and the regional language are also developed to enrich Indonesian itself. English language, one of the foreign languages that are the most widely used language, has led the Indonesian educational authorities to include it as an obligatory subject in school from elementary to university level. On the other hand, there are also regional 
languages that support the national language, such as the Mandailing language spoken by Mandailing people, especially those who live in Mandailing Natal regency.

In essence, of all the languages mentioned above, we can find similarities and differences between them if we examine them more deeply. Following the theory of language stated by the foremost expert, this is mentioned in some natures of language, including universal, arbitrary, and unique. According to Martinet (1987), language has some characteristics; one of those characteristics is that languages are similar. Although they are similar, one should realize that no two languages are the same. For example, in English and Mandailing Natal language, some differences exist between them, such as phonological, lexical, and grammatical, which are community regarded as the cause of learners' difficulties. However, there are some similarities between them in order in grammatical function, such as prefixes. In English and tribe language, each of them has its own system of word formation and has multiple meanings related to prefixes. Quoted Sapir (1921); Bauer (1983;2003b;2004); Trask (1993); Adams (2001); Katamba and Stonham (2006); Kridalaksana (2008); Hamawand (2011) mentioned prefixes were affixing that added in front of the root word.

With the explanation above, this study would like to present and compare prefixes in both two languages. According to James (1980:3); Richard \& Sehmidt (2002), the contrastive analysis compared two languages, for example, the sound system or the grammatical system. On the other side, Kridalaksana (2008:135) says that contrastive analysis in such an analysis was conducted to determine the differences and similarities of sound in different languages. Furthermore, this study will compare the word-formation, especially prefixes formulation between English and Mandailing Natal Languages. For this reason, to find the similarities and differences between them in the case of prefixes.

\section{Literature Review}

\subsection{English Prefixes}

In discussing prefixes, our understanding cannot be separated from word and morpheme. Words are the smallest elements of a language with practical meaning. Some consist of one morpheme, and the other consists of several morphemes, and morpheme are the smallest meaningful unit (Nida, 1994). Also, Hockett (1958:123); Gleason (1961: 52-52); Wardhaugh (1977:77); Trask (1997:144) stated that morpheme is the primary and smallest unit of a language and or morpheme is the minimal grammatical unit. On the other hand, morpheme that describes as the basis for words is sometimes called roots or bases (Crystal, 2008:313; Millaku, 2017). Its divided into morpheme, which can survive alone and has lexical meaning is called free morpheme, whereas morpheme cannot stand alone and should be attached to the root, stem, or base called bound morpheme (Plag, 2002). Indeed, bound morphemes occur only before other morphemes, such as un- 'uncover', dis- 'disconnect', pre- 'predetermine' (Katamba, 1993). Wider, some of the morphemes were attached to the beginning or the end of words; it is called affixes. According to Hall (2000); Fromkin, V., Rodman, R. (2003); Swan (2005); Templeton (2011); Bauer (2003) in Sasao \& Webb (2015); Yurtbaş1 (2015), affixes placed to the beginning of words are prefixes, and those assigned to the ends of words are suffixes. So, prefixes are a cluster of letters added before a word or base to convert its form and meaning to a new word.

Furthermore, Plag (2002:123-127) states that the prefixes on semantically can be classified into, 1) Quantified prefixes, such as, bi- (bilateral, bifurcation), di- (disyllabic), hyper- (hypersensitive, hypermarket), macro(macroeconomics, macro-biotic), micro- (micro-surgical, microwave), multi- (multi-racial, multi-lateral), over- (overestimate, overcook), poly- (polysyllabic, polyclinic), semi- (semi-conscious, semicircle), uni(unilateral, unification). 2) Locative prefixes, such as circum- (circumnavigate, circumscribe), counter(counterbalance, counterpart, counteract, ounterexample), endo- (endocentric, endocrinology), epi- (epiglottis, epicentral), inter- (intercultural, intergalactic, intermarry), intra- (intramuscular, intravenous). 3) Temporal prefixes, like ante- (antechamber, antedate), neo- (neoclassical, Neo-Latin), post-, (post-structuralism, postmodify, post-modern), pre- (preconcert, precondition) and. 4) Negation prefixes, it's to expressing negation like a- (achromatic, asexual), de- (decolonize, desegregate), dis- (disassociate, disadvantage), in- (illegal, irregular), non- (non-member, noncommercial), un- (unwrap, unsuccessful).

Broader understanding, Marchand (1969), whose approach is encyclopedic and historical, gives individual descriptions for 146 affixes in English 65 prefixes and 81 suffixes. Adams (2001) mentions in the Index of Word-Elements total affixes in English are 206 divided by 81 prefixes and 125 suffixes. On Cobuild corpus Hay and Baayan (2002), their research performed on a deal with 26 prefixes and 54 suffixes. Prc'ic' (2005) mention 95 prefixes, OED registers 167 prefixes, and in the research of Bauer (2003a) find out 47 prefixes in English, Lieber, (2005) mention there are seven prefixes in English. However, McCarthy (2002: 71) says that suffixes heavily outnumber prefixes in English derivational morphology. In the numbers mentioned above, it is clear that prefixes are out the number, but not heavily. The answer to this discrepancy lies in the frequency of use, which is higher for suffixes. So far, in describing individual affixes, Plag (1999; 2003:86-100; 2008) deals with 41 suffixes and only eight prefixes. 


\subsection{Mandailing Natal Language Prefixes}

Mandailingnes or now standard Mandailing has been variously spelled as Mengdelling, Mandahiling, Mandheling, Mendeheleng, Mandiling, Mandaling, Mendeleng, Mandailing Natal, etcetera (Mangaradja Ihoetan, 1926; Lubis, 2003). The Mandailing historically see themselves as a distinct and separate ethnic group in Indonesia. Mandailing language is widely spoken in the southern part of North Sumatra, especially in Mandailing Natal district called Madailing Godang. Although, according to Lubis (1998:1), in general, in the southern part of Tapanuli, there are two groups of people who depict that all South Tapanuli people (original ethnic) are considered Mandailing people. However, there is no doubt that some of them are also Angkola people, even though the Mandailing people themselves never considered or equated the Angkola people with the Mandailing people. In language, cultural customs have similarities, but there are still differences that need not be contested. Mandailing Natal culture is patriarchal, employing clan (marga), such as Lubis, Nasution, Parinduri, Batubara, Matondang, Daulae/y, and Hasibuan, Pulungan, Harahap, Rangkuti, Rambe.

In the book Comparative Languages has mentioned from the language family, Mandailing language is a region of the Western Austronesian family called the languages of Hesperanesia or Nusantara languages, the island languages Sumatra and its surroundings, in this region of existence Mandailing language (Mees, 1967). From its history based on Sahron Lubis, the Mandailing language is also influenced by the Minang language and Indonesian or Malay. Words such as godang 'big', kecek 'story', sirit 'dirt', etek 'aunt', mamak 'uncle', etc. are believed to have originated from the Minang language and words such ari 'day', hata' word', lambok 'soft', sikola 'school', sonang 'happy' others are thought to be from Indonesian (Lubis, 2009: 91).

Furthermore, Nasution (2005:14) said that speakers of Mandailing in daily conversation were divided into, 1) Hata na biaso, this language is used as an everyday language used in communication in the Mandailing community. 2) Hata andoeng di hatiha siloeloeton, this language is used in events or ceremonies of death and is also used by a girl when she says parting words in front of her parents when she is married to a man who will be her husband. 3) Hata si baso hatiha ni hadatoean, this language is usually used by village shamans when he encounters situations or events "possessed" by community members. 4) Hata teas dohot djampolak di hatiha parbadaan, this language is used as a language of advice or calm, especially on things or bad events such as fighting or commotion between members of the community. 5) Hata parkapoer hatiha di harangan, this language is used when someone is in the forest; in the past, this language was used by the Mandailing people who went to the forest to make a living.

In terms of word formation, mostly prefixes in Mandailing language, there are also prefixes. In Tohiruddin (1960: 6); Sohuturon (1960); Siregar (1977); Rangkuti (1983) states, "Na margoar panjoloi ima na ni tambahon tu sada hata sabola ngon jolo" (the prefix is an affix that is attached at the beginning of a word). There are so many prefixes in Mandailingnese, and here are some of them are commonly used in the daily life of Mandailing Natal people, such as 1) ma-, 2) pa-, 3) tar-, 4) tarpa-, 5) sa- and sasa-, 6) um-.

\section{Methods}

This research was conducted by using the descriptive method with a qualitative approach. According to Borg and Gall (1983: 354), a descriptive method is primarily concern with finding out "what is it". Description of "what is it" can be conducted by comparing and contrasting to discover the relationship between existing nonmanipulated variables. Qualitative studies are those in which the description of observation is not ordinally expressed in qualitative terms (Best, 1981: 12). It is not suggested that numerical measures are never used, but other means of description are emphasized. Simultaneously, Bogdan and Biklen (1992) declare that the qualitative approach is a direct source of data and the researchers as the principal instrument.

Based on the quotation above, the differences and similarities of prefixes both in English and Mandailing Natal languages have been done by comparing and contrasting the differences and similarities between them. The data of this research were prefixes in English and Mandailing Natal language. The data that were taken were focused on the form and meaning in both English and Mandailing language. The documentary technique was used to collect the data. The documentary technique means "read all the references". The require informative information was collected by reading and studying some references relate to the study.

The data were analyzed using contrastive analysis because it aims to find the similarities and differences between them. In carrying out the contrastive analysis, procedures were implemented: (1) Identifying the prefixes in English and Mandailing Natal language based on the types and meaning, (2) Determining the prefixes in English and Mandailing Natal Language, (3) Classifying the prefixes in both languages, (4) Contrasting the prefixes between English and Mandailing Natal language, (5) Finding out the differences and similarities between prefixes in English and Mandailing Natal language. 


\section{Results}

\subsection{English Prefixes}

According to Longman (1965:163), prefix consists of one or more syllables such as un-, pre-, super-, that are added to the beginning of a word or the basic part of the word (stem) to add to change is meaning. While, Katamba and Stonham (2006: 45); Lexico (2020) states a prefix is an affix attached before a root, base, or stems, like in-, re-, and un- and. While Jackson (2002: 77) holds that derivational morphemes (prefixes and suffixes) have the function of creating new words, whose meaning may in time develop away from that of the roots from which they are derived. In research White, Sowell, \& Yanagihara (1999); Raffelsiefen (1999) record lists the most common English prefixes: anti-, de-, dis-, en-, fore-, il-, in-, inter-, mid-, mis-, non-, over-, pre-, re-, semi-, sub-, super-, trans-, un-, under-.

Horby (1995: 909) emphasizes that the prefix is a or ground of letter inserted to the front of a word to amend its meaning. In short, it can be stated that all the affixes which appear before the words are called prefix. Take some examples, such as un- in unhappy, in- in immortal, il- in illegal. In this study, the writer only takes some prefixes that are commonly heard, such as mis-, pre-, in-, un-, hyper-, under-, super-, over-, inter-. This means that the prefix is derivational.

Prefix (un-)

Prefix (un-) means "not" appositive of. This prefix is attached to adjective/noun and Verb into an adjective.

Noun and Verb, it can be formulated as:

\begin{tabular}{llll}
\hline Un- + Adj & $=$ Adj & Un- + Real & $=$ Unreal \\
\hline Un- $+\mathrm{V} \quad=$ Adj & Un- + Kind & $=$ Unkind \\
\hline Un- $+\mathrm{V} \quad=$ Noun & Un- + Known & $=$ Unknown \\
\hline Un- + Noun $=$ Verb & Un- + Balance & $=$ Unbalance \\
\hline
\end{tabular}

Prefix (hyper-)

Prefix (hyper-) means "to a large degree."

This prefix can be attached to Noun and Adjective into Noun or Adjective.

It can be formulated as:

\begin{tabular}{lll}
\hline Hyper $-+=\mathrm{N}$ & Hyper- + Dominate & $=$ Hyperdominate \\
\hline Hyper- $+=$ Adj & Hyper- + Active & $=$ Hyperactive \\
\cline { 2 - 2 } Prer-) &
\end{tabular}

Prefix (under-) denotes of what is indicated in the base from this prefix can be attached to Noun and Verb. It can be formulated as:

Prefix (in-)

\begin{tabular}{lll}
\hline Under- $+\mathrm{N}=\mathrm{N}$ & Under- + Ground & $=$ Underground \\
\hline Under- $+\mathrm{V}=\mathrm{V}$ & Under- + Estimated & $=$ Underestimate \\
\hline
\end{tabular}

Prefix (in-) denotes before or in front of what is indicated in the base form.

The prefix in- can be attached to Adjective into Adjective this prefix can be formulated as:

$$
\text { In- (il) }+ \text { Adj }=\text { Adj In- (il) }+ \text { Legal = Ilegal }
$$

Prefix (mis-)

Prefix (mis-) means "wrong" this prefix can be attached to the Verb, Noun into Verb/Noun. Prefix mis- can be formulated as:

\begin{tabular}{lll}
\hline Mis- + Verb $=$ Verb & Mis- + Understand & $=$ Misunderstand \\
\hline Mis- + Noun $=$ Adj & Mis- + Statement & $=$ Misstatement \\
\hline
\end{tabular}

Prefix (super -)

Prefix super- denotes above or over of what is indicated in the base form. This prefix can be attached to Noun, Adjective. Prefix super- can be formulated:

\begin{tabular}{lll}
\hline Super- + Verb $=$ Verb & Super- + Market & $=$ supermarket \\
\hline Super- + Adj $=$ Adj & Super- + Natural & $=$ Supernatural \\
\hline
\end{tabular}


Prefix (over-)

Prefix (over-) means "very much". This prefix can be attached to a Verb or Adjective into Verb/Adjective. Prefix over can be formulated as:

\begin{tabular}{lll}
\hline Over -+ Verb $=$ Verb & Over- + Come & $=$ Overcome \\
\hline Over- + Adjective $=$ Adjective & Over- + Night & $=$ Overnight
\end{tabular}

Prefix (pre-)

Prefix (pre-) denotes before of what is indicated in the base form. This prefix can be attached to Noun and Adjective into Noun/Adjective.

Prefixes pre-can be formulated:

\begin{tabular}{lll}
\hline Pre- + Noun $=$ Noun & Pre- + History & $=$ Prehistory \\
\hline Pre- + Adjectie $=$ Adjective & Pre- + Historic & $=$ Prehistoric \\
\hline
\end{tabular}

\section{Prefix (inter-)}

Prefix (inter-) denotes "between" of what is indicated in the base form.

This prefix can be attached to the Verb and Noun into Verb/Noun.

Prefix inter- can be formulated as :

\begin{tabular}{lll}
\hline Inter- + Verb $=$ Verb & Inter- + act & $=$ Interact \\
\hline Inter- + Adjective $=$ Adjective & Inter- + Marriege & $=$ Intermarriage \\
\hline
\end{tabular}

Example in sentences:

1) Many people have an unreal expectation of what marriage will be like.

2) My daughter is a hyperactive child.

3) The parking area is standing at underground.

4) Impossible for me to be there before night.

5) He misunderstands her teacher about the meaning of the sentence.

6) She went to the supermarket last night.

7) We stayed overnight in French after the theatre.

8) The content of the book review is talking about prehistoric.

9) The teacher has a limited amount of time to interact with each child.

\subsection{Mandailing Natal Language Prefix}

\section{Prefix ma-}

Prefix ma- has some allomorphs depending on the sound of the base form it is attached. They are man-, mam, manga-, many-, and mar-. The meaning of these prefixes is "process of", the following are some examples of the prefix ma- when it is attached or added to the base form.

a. $\quad$ Ma- + Adjective $=$ Adjective

Example:

\begin{tabular}{ll}
\hline Ma- + Manis (sweet) & $=$ Mamanis (become sweet) \\
\hline Ma- + Deges (beutiful) & $=$ Madeges (become beautiful) \\
Ma- + Lagak (handsome) & $=$ Malagak (become handsome)
\end{tabular}

b. Man -+ Verb $=$ Verb

Example:

\begin{tabular}{ll}
\hline Man- + dai (to taste) & $=$ Mandai (taste) \\
\hline Man- + tangkup (to catch) & $=$ Manangkup (catch) \\
Man- + cubo (to try) & $=$ Mancubo (try) \\
\hline
\end{tabular}


c. Mam- + Verb $=$ Verb

Example:

\begin{tabular}{ll}
\hline Mam- + Basu (to wash) & $=$ Mamasu $($ wash) \\
\hline Mam- + Pio (to call) & $=$ Mamio $($ call $)$ \\
Mam- + Bongkar (break) & $=$ Mambongkar $($ break $)$
\end{tabular}

d. Mang- + Verb $=$ Verb

Example:

\begin{tabular}{ll}
\hline Mang- + Ompang (to close) & $=$ Mangompang (close) \\
\hline Mang- + Goar (to stir) & $=$ Manggoar (stir) \\
Mang- + Etong (to count) & $=$ Mangetong (count) \\
\hline
\end{tabular}

e. $\quad$ Manga- + Noun $=$ Verb

Example:

\begin{tabular}{ll}
\hline Manga- + Liang (hole) & $=$ Mangaliang $($ making a hole) \\
\hline Manga- + Rontok (cut) & $=$ Mangarontok $($ making a cut $)$ \\
\hline
\end{tabular}

f. Manya- + Verb $=$ Verb

Example:

\begin{tabular}{ll}
\hline Manya- + Sapu(broom) & $=$ Manyapu (sweep) \\
\hline Manya- + Suan (to plant) & $=$ Manyuan (plant) \\
Manya- + Tusuk (to stab) & $=$ Manyusuk $($ stab) \\
\hline
\end{tabular}

g. $\quad$ Mar- + Verb $=$ Verb

Example :

\begin{tabular}{ll}
\hline Mar- + Kusip (whisper) & $=$ Markusip (whisper) \\
\hline Mar- + Mayam (to play) & $=$ Marmayam (play) \\
Mar- + Lojong ( to run) & $=$ Marlojong (run)
\end{tabular}

Prefix pa-

Just like the prefix ma-, the prefix pa- also has some allomorphs which depend on the initial sound of the base form it is attached to. Prefix pa- can be attached to the base form of verbs and nouns.

a. When the prefix pa- is attached to the base form of verbs or nouns with the initial phoneme $[\mathrm{s}]$, the prefix pa- become pany-, and the phoneme [s] is omitted.

$\mathrm{Pa}-+\mathrm{Verb}=\mathrm{Verb}$

Example:

\begin{tabular}{ll}
\hline Pa- + Susun (to arrange) & $=$ Panyusun (arranger) \\
\hline Pa- + Simpan (to seve) & $=$ Panyimpan (sever) \\
\hline
\end{tabular}

b. When the prefix pa- is attached to the base form of verbs with the initial phoneme [t], it becomes pan- and phoneme $[\mathrm{t}]$ is omitted.

Pa -+ Verb $=$ Verb

Example:

\begin{tabular}{ll}
\hline Pa- + Tambat (to tie) & $=$ Panambat (tier) \\
\hline Pa- + Tempel (to stick) & $=$ Panempel (sticker)
\end{tabular}




Pa- + Taba (to fell) = Panaba (feller)

c. When the pa- is attached to the base form of the Verb with the initial phoneme [d], it becomes pan-.

Pa- + Verb $=$ Verb

Example:

\begin{tabular}{ll}
\hline $\mathrm{Pa}-+$ Jahit (to sew) & $=$ Panjahit (tailor) \\
\hline $\mathrm{Pa}-+$ Jago (to keep) & $=$ Panjago (keeper)
\end{tabular}

d. When the prefix pa-is added to the base form of the Verb with the initial phoneme [b], it becomes pam-.

Pa- + Verb $=$ Verb

Example:

\begin{tabular}{ll}
\hline Pa- + Bungkus (to pack) & $=$ Pambungkus (cover) \\
\hline $\mathrm{Pa}-+$ Baen (to make) & $=$ Pambaen (maker) \\
$\mathrm{Pa}-+$ Bunu (to kill) & $=$ Pambunu (killer)
\end{tabular}

e. When the prefix pa- is added to the base form of the Verb with the initial phoneme [p], it becomes pam- while the phoneme $[\mathrm{p}]$ is omitted.

$\mathrm{Pa}-+$ Verb $=$ Verb

Example:

\begin{tabular}{ll}
\hline $\mathrm{Pa}-+$ Pake (to use) & $=$ Pamake (user) \\
\hline $\mathrm{Pa}-+$ Pio $($ to call) & $=$ Pamio (caller) \\
\hline
\end{tabular}

f. When the prefix pa- is attached to the base form of Verb with the initial phoneme [g] or a vowel sound, it becomes pang-.

Pa- + Verb $=$ Verb

Example:

\begin{tabular}{ll}
\hline $\mathrm{Pa}-+$ Apus (erase) & $=$ Pangapus (eraser) \\
\hline $\mathrm{Pa}-+$ Gadis (to sell) & $=$ Panggadis (seller) \\
\hline
\end{tabular}

g. When the prefix pa- is attached to the Verbs base form with the initial phoneme [k], it becomes pang- and the phoneme $[\mathrm{k}]$ is omitted.

Pa- + Verb $=$ Verb

Example:

\begin{tabular}{ll}
\hline $\mathrm{Pa}-+$ Korot (to slice) & $=$ Pangorot (slicer) \\
\hline $\mathrm{Pa}-+$ Kirim (to send) & $=$ Pangirim (sender)
\end{tabular}

Prefix tar-

Prefix tar- has two possible meanings; they are "can be" and "unconsciously" based on the context.

Tar- + Verb $=$ Verb

Example:

\begin{tabular}{ll}
\hline Tar- + Godang (big) & $=$ Tarpagodang (eatable/eaten) \\
\hline Tar- + Oban (to brinng) & $=$ Taroban (can be brought) \\
\hline
\end{tabular}

Prefix tarpa-

Example:

\begin{tabular}{ll}
\hline Tarpa- + Deges (beautiful) & $=$ Tarpadeges (can be made beautiful) \\
\hline Tarpa- + Incat (higt) & $=$ Tarpaincat (can be made Hight) \\
\hline
\end{tabular}


Prefix sa- and sasa-

Example:

\begin{tabular}{ll}
\hline Sa- + Umak (mother) & = Saumak (has same a mother) \\
\hline Sa- + Huta (village) & $=$ Sahuta (live in the same village) \\
Sa- + Botol (bottle) & $=$ Sabotol (one bottle) \\
Sasa- + Orbo (buffalo) & $=$ Sasaorbo (as big as a buffalo) \\
\hline
\end{tabular}

Prefix um-

Prefix um- is used to slow comparative degree

Example:

\begin{tabular}{ll}
\hline Um- + Losok (lazy) & $=$ Umlosok (lazier) \\
\hline Um- + Pistar (clever) & $=$ Umpistar (cleverer) \\
Um- + Oto (stupit) & $=$ Umoto (more stupid)
\end{tabular}

Example in sentences:

1) Manjala ikan tu tobat.

2) Ijia isimpan ko pambungkus panganoni.

3) Taroban au buku ni dongan.

4) Inda be tarpatorang lampu ni kamar i.

5) Saumak dot saayah do ami.

6) Umpistar dope ia timbang au.

\subsection{The similarities of prefixes in English and Mandailing languages}

The findings of the similarities of prefixes in English and Mandailing Natal languages can be seen in the table below:

Table 1. Similarities of prefixes.

\begin{tabular}{lll}
\hline \multicolumn{1}{c}{ Meaning } & \multicolumn{1}{c}{ English } & \multicolumn{1}{c}{ Mandailing Natal Language } \\
\hline Based on type & In (il) + Legal $=$ Illegal & $\mathrm{Ma}+$ Jahit $=$ Manjahit \\
& Uni + Form $=$ Uniform & $\mathrm{Pa}+$ Susun $=$ Panyusun \\
\multirow{2}{*}{$\begin{array}{l}\text { Base on the } \\
\text { meaning }\end{array}$} & $\mathrm{Bi}+$ lingual $=$ Bilingual & \\
& Mil + Lateral $=$ Multilateral & $\mathrm{Sa}+$ Botol $=$ Sabotol \\
\hline
\end{tabular}

4.3 The differences of prefixes in English and Mandailing languages

While the differences of prefixes in English and Mandailing Natal languages can be read in the table presented below:

Table 2. Differences of prefixes.

\begin{tabular}{lcc}
\hline \multicolumn{1}{c}{ English } & $\begin{array}{c}\text { Mandailing Natal } \\
\text { Language }\end{array}$ & Meaning \\
\hline $\begin{array}{l}\text { The prefix in English has a negative meaning } \\
\text { Example: }\end{array}$ & $\varnothing$ & $\begin{array}{l}\text { Negative } \\
\text { Meaning }\end{array}$ \\
$\begin{array}{l}\text { In- (im) }+ \text { Possibe }=\text { impossible } \\
\text { Mis- }+ \text { Statement }=\text { Misstatement }\end{array}$ & $\varnothing$ & Pejorative \\
\hline $\begin{array}{l}\text { Prefix (mis-), (inter-), (super-) can be attached to } \\
\text { noun into noun }\end{array}$ & & \\
\hline$\varnothing$ & $\begin{array}{l}\text { Sasa- + Orbo } \\
\text { (bufallow) = sasaorbo } \\
\text { (as a big buffallow) }\end{array}$ & \\
\hline
\end{tabular}


Sasa- + Gaja

(elephant) = sasagaja

(as big a elephant)
Positive

degree

\section{Discussion}

After analyzing the data, this study findings indicate some differences and similarities in the morphological process of the prefix in English and Mandailing Natal language. Based on the table: 1, here are some similar meanings of prefix both in English and Mandailing Natal language, such as prefix, which is based on the type and based on the meaning. It is known that the similarities can be seen that there is the same way in arranging the word in both languages as in base on the type, e.g. (In (il) + Legal = Illegal and Ma + Jahit $=$ Manjahit) and base on the meaning, e.g. $(\mathrm{Bi}+$ lingual $=$ Bilingual and $\mathrm{Sa}+\mathrm{Botol}=\mathrm{Sabotol})$. Meanwhile, there are also differences way between English and Mandailing Natal language in arranging words by giving prefix. The example is seen from the table: 2 . differences of prefixes. The conclusion was drawn as follows: (1) There are some meanings of the prefix that can be found in one language but cannot found in the other, (2) There is a difference in the distribution of prefixes between English and Mandailing Natal language. For example: in English, there is a prefix which is used to indicate negative meaning which cannot found in Mandailing Natal language; in English, there is a prefix which is used to the pejorative meaning which cannot found in Mandailing Natal language. In Mandailing Natal language, there is a prefix used to form a positive degree that cannot be found in English.

\section{Conclusion}

This study's conclusion is about the implication of the findings' purposes for helping people interested in language study, specifically Mandailing Natal language. In hope, the process of prefixes should be taught through similar items first before the difference presented in the last. Thus it eases in the learning and designing the form of that languages in their mind. As a result, they can master the language as soon as possible. In further, it is hoped that these findings will be beneficial for linguists, especially in developing linguistics in the future.

\section{References}

Adams, V. (2001). Complex Words in English. London and New York: Routledge.

Anderson, B. (1991). Imagined Communities. London: Verso.

Batubara, M. H. (2020). On Speech Act Pragmatic: Political Languages In 2018 Elections In Aceh. International Journal of Humanity Studies, 3(2), 251-265. https://doi.org/doi.org/10.24071/ijhs.2020.030210

Bauer, L. (1983). English Word-Formation. Cambridge: Cambridge University Press.

Bauer, L. (2003a). English prefixation-atipological shift? Acta Linguistica Hungaria, 50(1-2), 33-40. https://doi.org/https://doi.org/10.1556/aling.50.2003.1-2.3

Bauer, L. (2003b). Introducing Linguistic Morphology (2nd edition). Edinburgh: Edinburgh University Press.

Bauer, L. (2004). A Glossary of Morphology. Edinburgh: Edinburgh University Press.

Best Jhon, W. (1981). Research In Education. New Jersey: Englewood_Clroiffs.

Bogdan, R.C., and Biklen, K. S. (1992). Qualitative Research for Education: An Introduction to Theory and Methods. Boston: Allyn and Bacon.

Borg, Walter. R. And Meredith, D. G. (1983). Educational Research. New York: Longman.

C. F. Hockett. (1958). A Course In Modern Linguistics. New York: Macmillan.

Carstairs-McCarthy, A. (2002). An Introduction to English Morphology. Edinburgh: Edinburgh University Press.

Crystal, D. (2008). A dictionary of Linguistics and Phonetics. U.K.: Blackwell Publishing.

Finch, G. (1998). How To Study Linguistics. New York: Palgrave Macmillan.

Fromkin, V., Rodman, R., \& H. N. (2003). An Introduction to Language (7th ed). USA: Thomson Wadsworth. Gellner, E. (1983). Nations and nationalism. Oxford: Blackwell.

Gleason, H. A. J. (1961). An Introduction to Descriptive Linguistics. New York: Holt, Rinehart, and Winston, Inc. 
Hall, C. J. (2000). Prefixation, suffixation and circumfixation. In Morphology. An international handbook on inflection and word formation. Handbooks of Linguistics and Communication Science (Booij, Gee, pp. 535-545). Berlin: De Gruyter.

Hamawand, Z. (2011). Morphology in English. Word Formation in Cognitive Grammar. London, New York: Continuum International Publishing Group.

Horby, A. . (1995). Oxford Advanced Learner's Dictionary Of Current English. Oxford: Oxford University Press.

Huddleston, Rodney, G. P. (2002). The Cambridge Grammar of the English Language. Cambridge: Cambridge University Press.

Jackson, H. (2002). Grammar and Vocabulary. London: Routledge.

James, C. (1980). Contrastive Analysis. Harlow: Longman.

Jennifer Hay, H. B. (2002). Parsing and productivity. In G. B. Van Marle (Ed.), Yearbook of Morphology 2001 (pp. 203-235). Berlin, Jerman: Springer-Science+Business Media, B.V.

Katamba, F, and Stonham, J. (2006). Morphology. New York: Palgrave Macmillan.

Katamba, F. (1993). Morphology. New York: St Martin's Press.

Kridalaksana, H. (2008). Kamus Linguistik (Edisi Keen). Jakarta: PT Gramedia Pustaka Utama.

Lehrer, A. (1993). Prefixes in English Word. The Third International Cognitive Linguistics Conference Folia Linguistica XXIX/1-2, 133-148. $\quad$ Retrieved from https://alehrer.faculty.arizona.edu/sites/alehrer.faculty.arizona.edu/files/Prefixes in English word formation.pdf

Lexico. (2020). Affix. Retrieved March 26, 2020, from Lexico.com website: https://www.lexico.com/definition/affix

Lieber, R. (2005). English Word-Formation Processes. In R. L. Štekauer, Pavol (Ed.), Handbook of WordFormation (pp. 375-427). Dordrecht: Springer.

Longman. (1965). Dictionary Of Grammar And Usage. New York: Longman.

Lubis, A. R. (2003). Transformation Of Mandailing Cultural Identity And Leadership. Journal of the Malaysian Branch of the Royal Asiatic Society, 76(1) (284), 55-79. Retrieved from www.jstor.org/stable/41493487

Lubis Pangaduan. Z dan Zulkifli Lubis. (1998). Sipirok Na Soli Bianglala Kebudayaan Masyarakat Sipirok. Medan: Badan Pengkajian Pembangunan Sipirok dan USU Pres.

Lubis, S. (2009). Penerjemahan Teks Mangupa dari Bahasa Mandailing ke dalam Bahasa Inggris. Sekolah Pascasrajana Universitas Sumatera Utara, Medan.

Mangaradja Ihoetan. (1926). Asal-Oesoelnja Bangsa Mandailing: Berhoeboeng dengan Perkara Tanah Wakaf Bangsa Mandailing, di Soengei Mati-Medan. Medan: Pewarta Deli.

Marchand, H. (1969). The Categories and Types of Present-Day English Word-Formation: A SynchronicDiachronic Approach, Second edition. Munich: C. H. Beck’sche Verlagsbuchhandlung.

Martinet, A. (1987). A Functional View of Language. London: Oxford University Press.

Mees, C. . (1967). Ilmu Perbandingan Bahasa-Bahasa Austronesia. Kuala Lumpur: University of Malaya Press.

Nasution, H. P. (2005). Adat Mandailing Dalam Tantangan Zaman. Sumatera Utara: FORKALA.

Nida, E. A. (1994). Morphology: The Descriptive Analysis Of Words. Annarbour: The University of Michigan Press.

Plag, I. (1999). Morphological Productivity: Structural Constraints in English Derivation. Berlin and New York: Mouton de Gruyter.

Plag, I. (2002). Word-formation in English. Series' Cambridge Textbooks in Linguistics'. Cambridge. Cambridge: Cambridge University Press.

Plag, I. (2003). Word-formation in English. Cambridge: Cambridge University Press.

Plag, I. (2008). Word-formation in English. Cambridge: Cambridge University Press.

Prc'ic', T. (2005). Prefixes Vs Initial Combining Forms In English: A Lexicographic Perspective. International Journal

of Lexicography, 18(3),

313-334. 
https://doi.org/https://www.researchgate.net/deref/http\%3A\%2F\%2Fdx.doi.org\%2F10.1093\%2Fij1 $\% 2$ Feci026

Quirk, Randolph, Sidney Greenbaum, Geoffrey Leech, J. S. (1985). A Comprehensive Grammar of the English Language. Harlow: Pearson Education.

R. L. Trask. (1993). A Dictionary of Grammatical Terms in Linguistics. London and New York: Routledge.

R. L. Trask. (1997). A Students Dictionary of Language and Linguistics. London: Arnold.

Raffelsiefen, R. (1999). Phonological constraints on English word- formation. In Geert Booij \& Jaap van Marie (Ed.), Yearbook of Morphology 1998 (pp. 225-287). Boston, Dordrecht, London: Kluwer.

Rangkuti, N. (1983). Bahasa Daerah:Angkola dan Mandailing. Medan: Unpublish.

Richard, J.C, \& Sehmidt, R. (2002). Longman Dictionary of language teaching and applied linguistics (3rd ed). Harrow, Esser: Longman Group Limited.

Sapir, E. (1921). Language. New York: Harcourt, Brace and Company.

Sasao, Y., \& Webb, S. (2015). The word part levels test. Language Teaching Research, 21(1), 12-30. https://doi.org/https://doi.org/10.1177/1362168815586083

Shkëlqim Millaku. (2017). The Prefixes and Suffixes of Albanian and English Language. International Journal of ANGLISTICUM Literature, Linguistics and Interdisciplinary Studies, 6(7), 20-36. https://doi.org/http://dx.doi.org/10.0001/(aj).v6i7.1483

Siregar, A. S. (1977). Kamus Bahasa Angkola/Mandailing - Indonesia. Jakarta: Pusat Pembinaan dan Pengembangan Bahasa. Departemen Pendidikan dan Kebudayaan.

Sohuturon, B. R. (1960). Ruhut Manjuratkon Hata Batak Angkola Mandailing. Padangsidempuan: Pustaka Timur.

Swan, M. (2005). Practical English usage ((3rd ed)). New York: Oxford University Press.

Templeton, S. (2011). Teaching and learning morphology: A reflection on generative vocabulary instruction. The Journal of Education, 192(2/3), 101-7.

Retrieved

from https://www.researchgate.net/profile/Shane_Templeton/publication/283016139_Teaching_and_Lear ning_Morphology_A_Reflection_on_Generative_Vocabulary_Instruction/links/56266b7a08ae4d9e5 c4ce043/Teaching-and-Learning-Morphology-A-Reflection-on-Generative-VocabularyInstruction.pdf

Tohiruddin. (1960). Biado Panyuratkon Hata Hita. Padang Sidempuan: Pustaka Timur.

Walter, H. (1988). Le français dans tous les sens. Paris: Robert Laffont.

Wardhaugh, R. (1977). Introduction to Linguistics. New York: McGraw-Hill Book Company.

White, T. G., Sowell, V., \& Yanagihara, A. (1999). Teaching elementary students to use word part clues. The Reading Teacher, 42, 302-308.

Wright. S. (2015). What is language? A response to Philippe van Parijs. Critical Review of International Social and Political Philosophy, 18(2), 113-130. https://doi.org/10.1080/13698230.2015.1023628

Wright, S. (2004). Language policy and language planning. Basingstoke: Palgrave.

Yurtbaş1, M. (2015). Building English vocabulary through roots prefixes and suffixes. Global Journal of Foreign Language Teaching, 5(1), 44-51. https://doi.org/http://dx.doi.org/10.18844/gjflt.v5i0.39 